\title{
Children and adolescents with cerebral palsy in the perspective of familial caregivers
}

\author{
Rosane Maria dos Santos ${ }^{(1)}$ \\ Giselle Massi( ${ }^{(2)}$ \\ Mariluci Hautsch Willigi(3) \\ Luciana Branco Carnevale ${ }^{(4)}$ \\ Ana Paula Berberian ${ }^{(2)}$ \\ Márcia Helena de Souza Freire ${ }^{(3)}$ \\ Rita Tonocchi(2) \\ Telma Pelaes de Carvalho(5)
}

(1) Universidade Federal do Paraná, Hospital de Clínicas, Serviço de Cirurgia Pediátrica. Curitiba, Paraná, Brasil.

(2) Universidade Tuiuti do Paraná, Curitiba, Paraná, Brasil.

(3) Universidade Federal do Paraná, Curitiba, Paraná, Brasil.

(4) Universidade Estadual do Centro-Oeste (UNICENTRO), Irati,Paraná, Brasil.

(5) Instituto Federal do Paraná, Ensino básico técnico e tecnológico (EBTT). Curitiba, Paraná, Brasil.

\section{Conflict of interest: Nonexistent}

Received on: June 07, 2017

Accepted on: September 19, 2017

\section{Mailing address:}

Giselle Massi

Rua Benjamin Lins, 750, ap. 61, Batel

CEP: 80:420-100 - Curitiba, Paraná, Brasil Email: giselle.massi@utp.br

\section{ABSTRACT}

Objective: to analyze family caregivers' perceptions on care delivered to children and adolescents presented with cerebral palsy.

Methods: a quantitative, qualitative study developed with 50 family caregivers of children and adolescents diagnosed with cerebral palsy. Data collection was carried out by means of an interview with semi-open questions whose answers were analyzed based on the Content Analysis.

Results: family members' accounts on care delivered to children and adolescents with cerebral palsy are mostly connected with positive feelings, such as love, happiness, privilege and overcoming. However, for a significant share of these family members, their own quality of life depends on the cared subject's health condition, blurring the distinction between their own needs and those of the cared subjects.

Conclusions: health professionals need to recognize the importance of caregivers' health promotion as a major condition to keep caring. In this dimension, they may contribute by helping caregivers identify their own health needs.

Keywords: Cerebral Palsy; Child Care; Caregivers 


\section{INTRODUCTION}

Caring for children and adolescents with cerebral palsy in the family context entails challenging situations. The challenge is usually due to family's lack of knowledge on the specificities of that irreversible disability characterized by permanent neuromotor disorders along those subjects' lives. In this perspective, uncertainties are common as well as workload of family caregivers, which increases as the cared person grows older, thus often resulting in physical and emotional distress for the caregivers. This way, it is deemed to consider that the dedication to people suffering from cerebral palsy takes time and energy, entailing difficulties for family caregivers to plan and carry out their own short and medium-term personal projects, which hinders their well-being ${ }^{1}$.

Thus, it is necessary to point out the importance of health professionals to care for family caregivers of children and adolescents with cerebral palsy. Therefore, they need to identify their difficulties and necessities related to their quality of life and the subjective constitution of their well-being. In this process, the construction of a bond of trust between the family caregiver and the health professional from the initial contact is pointed out, as well as the development of educational interventions, which may reduce aggravations in their social and health condition due to physical and emotional distress occurring in this caring context.

Under such understanding, it is possible to state that, in the caring process, it is necessary to learn to care for the other and for oneself. That implies the access to information related to the specific knowledge of human care, as well as family caregivers' empowerment, bringing about their critical thinking, which will enable them to transform the reality where they live $i^{2}$.

Cerebral Palsy (CP) is a chronic condition featuring a number of functional impairments due to changes in the development of the central nervous system ${ }^{3,4}$. It is described as a permanent motor change caused by non-progressive disorders occurring in the developing fetal or infant brain ${ }^{4}$.

Motor sequelae in the CP are commonly followed by disorders in the sensation, perception, cognition, communication and behavior, by epilepsy and secondary muscle-skeletal problems ${ }^{5}$. Therefore, brain changes present in the person suffering from cerebral palsy are a biological limitation that may hinder the typical brain development, causing intellectual impairment or specific cognitive disorders ${ }^{6}$.
Despite the relatively steady incidence of cerebral palsy in the so-called developed countries ${ }^{7}$, the estimated prevalence has been rising with an average of 3.6 cases out of 1,000 children in three areas in the United States of America ${ }^{8}$. It is worth pointing that CP is one of the commonest impairing conditions among schoolchildren, accounting for $67 \%$ of the severe motor disabilities in childhood'.

In Brazil, there are 45,606,048 people with some kind of disabilities, among the reported ones are, as follows: visual, hearing, motor, mental or intellectual ones, taking up $24.9 \%$ of the total population ${ }^{10}$. It is considered that, depending on the disability, people need help to live and care for themselves, being essential the presence of a family caregiver.

Connected relationships with the caring act imply several physical, social, cognitive and emotional adaptations, which usually reflect a hard, stressful process for family caregivers, who usually end up hindering their own health. By taking on this role, caregivers take responsibilities, usually associated with cultural values and morally-imposed issues by the society. In other words, they are compelled to meet certain social demands, related to an idealized totally dedicated parent, resulting in greater personal distress ${ }^{11}$.

Thus, the current study aims to analyze family caregivers' perceptions on caring for children and adolescents with cerebral palsy, identifying, in their accounts, the understanding they have about their own Quality of Life, and about their Rights and Duties.

\section{METHODS}

The study was approved by the Ethics Board of the Hospital de Clínicas, Universidade Federal do Paraná, according to the Certificate of Presentation for Ethical Consideration: 21932013.5.0000.0096, October, 2013.

It is a quantitative, qualitative study carried out according to the Resolution 466/2012 of the National Health Council, complying with the ethical guidelines of voluntary, informed participation, having all participants filled out the free, informed consent form ${ }^{12}$.

\section{Participants}

Fifty family caregivers of children and adolescents with cerebral palsy treated at a teaching hospital from the Brazilian Unified Health System, located in Southern Brazil, participated in the study. As an inclusion criterion, family members should be aware of the cared 
subject's diagnosis of cerebral palsy. Caregivers, who expressed their wish to discontinue their participation in the research, were excluded. In order to select the study participants, a direct approach was chosen in the outpatient settings of the previously mentioned teaching hospital. That hospital assists patients from all regions of the country.

\section{Procedures}

Information was collected between January and March of 2014. The selected instrument was a semiguided interview with semi-open questions, built by the authors. The initial questions of the questionnaire aimed at obtaining participants' sociodemographic features, followed by semi-open questions, which enabled participants' accounts on the caring act, as well as aspects regarding their quality of life, and their knowledge on their own rights and duties. Two pilot-interviews were carried out in order to verify the adequacy and feasibility for the use of the instrument. It was not necessary to change it as questions were pertinent for the development of the study and fully accessible to the caregivers. The interview was individually carried out, and its application took about one hour for each participant.

\section{Information analysis}

Content Analysis (CA), method developed by Bardin $^{13}$, which enables quali-quantitative data treatment, was used to organize the collected information. CA organization comprises three chronological poles: (a) pre-analysis, (b) material analysis, and (c) treatment of results and interpretations. In the pre-analysis, the fluctuating reading of the material is carried out. In the pole regarding material exploration, apart from codification operations of the material, register units are organized, and thematic categories are delimited. Finally, in the last pole regarding treatment of results and interpretations, statistical operations, synthesis and result selection are carried out, as well as their inferences and interpretations ${ }^{13}$.

Grounded in the CA method, the current study developed a thematic category analysis, based on the participants' responses, and statistical operations were also carried out. From a quantitative focus, data were submitted to inferential, descriptive, statistical analysis, displayed in a table and chart, facilitating their visualization. Quantitative variables were expressed by frequencies and percentages, mean, median and standard deviation.

On the other hand, qualitative data were organized according to three thematic categories: (1) meanings expressed by family caregivers on the caring act; (2) understandings that family caregivers of subjects with cerebral palsy have about their own Quality of Life, and (3) family caregivers' knowledge on their Rights and Duties. Apart from being statistically treated, these categories consider interviewed participants' own expressions and enunciates, identified by numbers from 1 to 50 .

\section{RESULTS}

The results on the frequency distribution of sociodemographic characteristics from family caregivers of children and adolescents with Cerebral Palsy are shown in TABLE 1.

Figure 1 shows the synthesis of the results regarding thematic category analysis, as follows.

Regarding Thematic Category 1, related to the perceptions of family caregivers of subjects with cerebral palsy on their caring act, the answers expressed by most research participants evidence positive feelings, such as: love, affection, privilege, overcoming, learning and pleasure of caring, besides religious strengthening, as it is possible to follow in the accounts below.

I'm feeling very well because I do everything with great love and affection, because there is no greater love than mother's love. (17)

Privileged, because we learn to value small things with them, to value the life. (07)

I feel fine, I think God enabled me to take care of him, and every day, l've learned by watching his overcoming, will to live and grow up. (12)

Another group of the study participants claims that they take such care in a negative way when they were questioned about caring for a child or adolescent with cerebral palsy. Such perceptions are mentioned in the accounts below: 
Table 1. Frequency distribution of the sociodemographic characteristics from family caregivers of children and adolescents with cerebral palsy

\begin{tabular}{|c|c|c|c|}
\hline Variável & Classification & $n$ & $\%$ \\
\hline \multirow{7}{*}{ AGE } & Less than 20 years & 1 & 2.0 \\
\hline & 20 to 29.9 years & 15 & 30.0 \\
\hline & 30 to 39.9 years & 13 & 26.0 \\
\hline & 40 to 49.9 years & 15 & 30.0 \\
\hline & 50 years or older & 2 & 4.0 \\
\hline & Did not answer & 4 & 8.0 \\
\hline & Total & 50 & 100.0 \\
\hline \multirow{3}{*}{ GENDER } & Females & 47 & 94.0 \\
\hline & Males & 3 & 6.0 \\
\hline & Total & 50 & 100.0 \\
\hline \multirow{6}{*}{ SCHOOLING } & Incomplete Middle School & 11 & 22.0 \\
\hline & Complete Middle School & 15 & 30.0 \\
\hline & High School & 19 & 38.0 \\
\hline & Higher Education & 4 & 8.0 \\
\hline & & 1 & 2.0 \\
\hline & Total & 50 & 100.0 \\
\hline \multirow{5}{*}{ MARITAL STATUS } & Married & 36 & 72.0 \\
\hline & Divorced & 6 & 12.0 \\
\hline & Single & 7 & 14.0 \\
\hline & Widow(er) & 1 & 2.0 \\
\hline & Total & 50 & 100.0 \\
\hline \multirow{6}{*}{ RELIGION } & Catholic & 31 & 62 \\
\hline & Evangelical & 15 & 30 \\
\hline & Non-defined & 1 & 2.0 \\
\hline & Another & 2 & 4.0 \\
\hline & Did not answer & 1 & 2.0 \\
\hline & Total & 50 & 100.0 \\
\hline \multirow{6}{*}{ WORK AND OCCUPATION } & Self-employed without a formal job & 7 & 14.0 \\
\hline & Unemployed & 22 & 44.0 \\
\hline & Formally employed & 10 & 20.0 \\
\hline & Student & 1 & 2.0 \\
\hline & Other temporary occupations & 10 & 20.0 \\
\hline & & 50 & 100.0 \\
\hline \multirow{5}{*}{ HOUSING } & Rented housing & 13 & 26.0 \\
\hline & Freely-provided housing & 2 & 4.0 \\
\hline & Own housing & 32 & 64.0 \\
\hline & Live for free with family members & 3 & 6.0 \\
\hline & Total & 50 & 100.0 \\
\hline \multirow{3}{*}{ RECEIVES A JOB SALARY } & No & 28 & 56.0 \\
\hline & Yes & 22 & 44.0 \\
\hline & & 50 & 100.0 \\
\hline \multirow{6}{*}{ FAMILY RELATIONSHIP } & Grandmother & 2 & 4.0 \\
\hline & Sister & 3 & 6.0 \\
\hline & Mother & 40 & 80.0 \\
\hline & Another & 2 & 4.0 \\
\hline & Father & 3 & 6.0 \\
\hline & Total & 50 & 100.0 \\
\hline
\end{tabular}




\begin{tabular}{|c|c|c|}
\hline Thematic Category & Units of meaning & Frequency \\
\hline \multirow{4}{*}{$\begin{array}{l}\text { 1) Perceptions ex- } \\
\text { pressed by family } \\
\text { caregivers on the } \\
\text { caring act }\end{array}$} & Caring as a duty, burden due to lack of support; & $(n=6) 12 \%$ \\
\hline & Caring permeated by uncertainty and guilt; & $(n=4) 8 \%$ \\
\hline & $\begin{array}{l}\text { Caring permeated by feelings of love, affection, happiness, privilege, over-coming, learning and } \\
\text { religious strengthening. }\end{array}$ & $(n=40) 80 \%$ \\
\hline & Total & $(n=50) 100 \%$ \\
\hline \multirow{8}{*}{$\begin{array}{l}\text { 2) Family caregiv- } \\
\text { ers' understand- } \\
\text { ings about their } \\
\text { own Quality of Life }\end{array}$} & $\begin{array}{l}\text { Quality of Life associated with better healthcare service and quality medi-cation for the subject } \\
\text { with CP; }\end{array}$ & $(n=4) 8 \%$ \\
\hline & $\begin{array}{l}\text { Quality of Life associated with the improvement in the mobility, safety and accessibility of the } \\
\text { subject with CP; }\end{array}$ & $(n=6) 12 \%$ \\
\hline & $\begin{array}{l}\text { Quality of Life associated with the improvement in the basic survival conditions of subjects } \\
\text { with CP; }\end{array}$ & $(n=7) 14 \%$ \\
\hline & $\begin{array}{l}\text { Quality of Life associated with feel-ings of happiness, solidarity and life-style of the subjects } \\
\text { with CP; }\end{array}$ & $(n=10) 20 \%$ \\
\hline & Quality of Life associated with feel-ings of happiness, solidarity and life-style of the caregivers; & $(n=7) 14 \%$ \\
\hline & Quality of life associated with the im-provement in the caregivers' basic survival conditions; & $(n=11) 22 \%$ \\
\hline & Did not answer. & $(n=5) 10 \%$ \\
\hline & Total & $(n=50) 100 \%$ \\
\hline \multirow{15}{*}{$\begin{array}{c}\text { 3) Family } \\
\text { caregivers' } \\
\text { knowledge on their } \\
\text { Rights and Duties }\end{array}$} & Rights & \\
\hline & $\begin{array}{l}\text { Rights associated with the subject with CP, who deserves to be cared and treated respectfully, } \\
\text { without ex-clusion; }\end{array}$ & $(n=15) 30 \%$ \\
\hline & $\begin{array}{l}\text { Rights associated with the subject with CP, who deserves to have healthcare, education, } \\
\text { accessibility and transportation; }\end{array}$ & $(n=14) 28 \%$ \\
\hline & Rights associated with the subject with CP, who deserves to live as a normal person; & $(n=1) 2 \%$ \\
\hline & Do not know their rights; & $(n=3) 6 \%$ \\
\hline & Right associated with caregivers' happiness; & $(n=2) 4 \%$ \\
\hline & Did not understand what was asked; & $(n=6) 12 \%$ \\
\hline & Did not answer. & $(n=9) 18 \%$ \\
\hline & Total & $(n=50) 100 \%$ \\
\hline & Duties & \\
\hline & Caring for the subject with CP with love, affection, respect, dedication, diligence and safety; & $(\mathrm{n}=20) 40 \%$ \\
\hline & Caring for the basic human needs of the subject with CP; & $(n=13) 26 \%$ \\
\hline & Did not understand what was asked; & $(n=6) 12 \%$ \\
\hline & Did not answer. & $(\mathrm{n}=11) 22 \%$ \\
\hline & Total & $(n=50) 100 \%$ \\
\hline
\end{tabular}

Figure 1. Synthesis of the thematic category analysis regarding family caregivers' perception on the caring act

There are times I feel guilty for him to be like that, I don't know, I wish I could do something to cure him, for him not to have to go through that anymore. (26)

\section{If I had support to care for her, I'd feel happier to} help. (01)

\section{A burden for a mother, mainly for not getting any kind of financial assistance. (11).}

Regarding Thematic Category 2, the perception of family caregivers of subjects with cerebral palsy on their quality of life, results evidence that most participants in this research study associate their well-being with the benefits obtained by those who are cared for, according to the accounts, as follows:

You could give him better clothes, better food. (46)

A better life for our children. (20)

Caring for him, for my family. (11)

A broader and better life for the disabled. (42)

Quality healthcare service for my child. (44)

Regarding Thematic Category 3, knowledge of family caregivers about their own rights and duties, results showed that a significant number of the study participants associate their own rights with their 
children's rights, those that they care for $(86 \%$ of these participants are parents of those subjects):

My son has the right to be treated well. (02)

He has the right to be respected, not humiliated. (14 e 21)

Suffering less prejudice, less bullying at school. (04)

She deserves better space to express herself. (41)

The right for public transportation and decent priority healthcare in the public healthcare system. $(38,43$, 46, 37).

Still related to the Thematic Category 3 , more specifically regarding caregivers' duties, the study participants claim that caring for children and adolescents with cerebral palsy must be permeated by love, affection, dedication, diligence and safety:

Caring well and patiently, with diligence and love in what I do. $(08,40,06,46,44,20)$

Believing in the recovery every day, it's my duty to keep calm and trust. (48)

Helping and providing the best for my son, such as: health, schooling, and whatever is necessary for him to be a normal person in society. (02)

Food and body hygiene, keeping him clean and dry for 24 hours. $(11,13)$

Taking him to the doctor's appointments and following his/her guidance. (27, 28 e 50)

\section{DISCUSSION}

Data related to the sociodemographic profile from the sample in the current study show that most participants are married women, mothers, catholic, mean age of 35.2 years (median of 34.5 and standard deviation of 10.5 years), and high school as their educational level. Moreover, the greatest part is unemployed, does not get any wages, has a stable family relationship and lives in her own housing.

Part of the results found are compatible with the ones from a Brazilian research study, which evidences that $95 \%$ of caregivers of children with cerebral palsy are women with mean age of 39 years $^{14}$. According to other research studies, the current study also evidences that mothers usually take the role of caregivers for their children with cerebral palsy in Brazil, to the extent that women are traditionally held responsible for their family members' care ${ }^{15,16}$. As for religion, other studies still show that mothers responsible for caring people presented with cerebral palsy are Catholic ${ }^{17,18}$.

Regarding the discussion of thematic categories, the first one related to the meanings expressed by family caregivers of subjects with cerebral palsy and the caring act, it is possible to state that caregivers' relation to the cared subjects is perceived as gratifying and a reason for them to value their own lives, having in mind that $94 \%$ of them are women. Similar data are recorded by another study, which focuses on Brazilian family caregivers, for whom caring brings about mixed feelings of suffering and renounce, but such dedication is ultimately compensated by the motor and cognitive gains due to their child's rehabilitation ${ }^{18}$.

The search for support in the religion is also corroborated by more Brazilian studies held with family caregivers of people with CP. These studies evidence that those caregivers, mostly females and mothers, face implied difficulties to the caring act, thus they turn to religion, attributing their own personal strength to a Supreme Being. The caregivers find it relevant to "search for God" in their moments of anguish, pain and discouragement after relief, consolation and the strength they need. They consider themselves as chosen to perform the mission of being mothers of such subjects, therefore, feeling privileged for the act of caring in this context ${ }^{19,20}$.

On the other hand, it is deemed to consider that a minority of the participants disclosed a distinct feeling from the one mentioned above regarding the caring act. This smaller number of the researched population states that they perceive caring as a duty, a burden due to the lack of support to carry it out. Uncertainty and guilt were also expressions that permeate their accounts. Similar results were verified in a study held with family members in a subsequent period to the disclosure of their child's cerebral palsy diagnosis. The authors pointed out guilt and fear in those parents' accounts for the changes in the daily routine accounts ${ }^{20}$. Moreover, it should be pointed out that family caregivers need to develop an attitude of coping, of resilience in face of an array of changes in their personal and family lives ${ }^{21}$. Thus, health promotion programs must be implemented in order to offer friendly spaces for experience exchange among all the subjects involved in caring for people with $\mathrm{CP}$.

Content analysis of Thematic Category 2, related to family caregivers' perception on their quality of life, 
disclosed that most subjects in this study associate their own well-being with the benefits obtained by those whom they care for. Practically half of the participants in this study associate their quality of life with better survival conditions for the subjects with cerebral palsy, which shows that the caregivers cannot conceive their quality of life independently from their children's comfort, due to the disability of the latter subjects.

In relation to the Quality of Life (QL), it has been studied from different factors, such as satisfaction, happiness, freedom and personal fulfillment, perception of well-being, access to cultural events and leisure, among other aspects. Thus, although there is not common agreement on the definition of QL, the World Health Organization proposes major issues to be considered regarding such a concept: subjectivity; multidimensionality, which includes physical, psychological and social dimensions; bipolarity, with the presence of positive and negative aspects; and finally, changeability, which involves changes in the perception of the quality of life according to the time, place and cultural context that people are inserted ${ }^{22}$.

Cultural expectations of gender, family relations, housework and child rearing, which permeate Western societies, make women dedicate themselves to take care of their offspring, overcoming their own limits, even if such dedication has been turned into voluntary sacrifice to benefit their children and their own families ${ }^{19}$. Therefore, by referring to the quality of life of caregivers of children and adolescents with cerebral palsy, it deems necessary for health professionals to be aware of the significant proximity between both, caregivers and cared subjects, in such a way that the change into the quality of life of one of them interferes in the wellbeing of the other.

In this dimension, health professionals must be qualified to deliver comprehensive and collective care, and overcome the individualized, fragmented view of healthcare. It is assumed that caring for caregivers' health makes it possible to improve the quality of life of children with special needs, and consequently, that of their family members. Thus, it should be pointed out the relevance of sharing experiences between professionals and family members enabling clarification, approaching, coping with the fears and uncertainties that permeate such life contexts ${ }^{23}$.

Thematic Category 3, related to the knowledge of family caregivers of subjects suffering from cerebral palsy on their own rights and duties, evidenced that a considerable of the participants in this study associate their rights with those of the children and adolescents with cerebral palsy. Thus, they claim that their children have the right to be respectfully cared and treated.

It should be pointed out that children and adolescents suffering from such a condition have the right for treatment, education and special care required for their unique disability; they have the right to live in an affectionate and safe environment, whenever it is possible, under their parents' care and responsibility. They must also have priority to get protection and aid in case of public disaster; they must get protected from all forms of neglect, cruelty, exploitation and discrimination ${ }^{24}$. However, it is necessary that caregivers consider that they also have the right to fulfil their wishes, and to be assisted with their needs, besides leading a healthy life, because they end up jeopardizing their life and the one from their cared subjects, targets of their care.

In general, family caregivers are lay people, who take on tasks for those they are not prepared for ${ }^{25}$. Therefore, it is important that health professionals have the sensitiveness to deal with such caregivers, talk to them, inform them and empower them, fostering conditions for coping with daily situations which involve the caring subjects and the cared ones altogether. In other words, health professionals need to be able to work for family caregivers' empowerment, expanding their knowledge and possibilities to influence the processes who determine their lives.

The partnership between health professionals and family caregivers must enable task accomplishment in household settings, which makes feasible activity systematization related to health promotion, disability prevention and maintenance of caregivers' and caredependent subjects' functional capacity ${ }^{25}$.

In family caregivers' point of view, Brazilian society usually isolates and rejects people with cerebral palsy in the form of denial/rejection stemming from the social value attributed to the perfect physical body, which conveys differences such as deficits, needs or disabilities ${ }^{26}$. Thus, it must be considered that prejudice is a social problem, which should not be treated or perceived as individual issues, being the task of professionals involved with the caring process to children and adolescents with $\mathrm{CP}$, to inform and make family caregivers aware of the current legislation regarding protection and benefits granted to disabled people and their families.

As for family caregivers' duties, part of the participants in this study understand that care for children and adolescents with cerebral palsy must be permeated by 
love, affection, dedication, diligence and safety. On the other hand, another number of family caregivers refer that such care needs to comprise the basic human needs, that is, food, body hygiene, education, health and treatment of those subjects.

A study carried out with family caregivers of chronic individuals evidences that the more care the subject requires, the more isolated caregivers tend to feel from the other family members and the social context, which hinders their chances for leisure as well as their daily routine ${ }^{27}$. Therefore, the development of initiatives which promote the bonds between the health professional and caregiver is essential, once caregivers themselves depend on this approaching and empowering educational interventions to carry out effective caring attitudes ${ }^{28}$.

That social networks are strong allies to overcome family difficulties emerging along the course of a chronic disease is widely known among health professionals. Thus, such professionals need to consider the importance of creating networks when a family is facing conflicting moments, encouraging the construction of social groups capable of strengthening the coping with chronic diseases in childhood and adolescence ${ }^{29}$.

The results from this current study enable health professionals to broaden their understanding on the meaning of the caring act to family caregivers. It is expected that the spread of these findings facilitates the organization of initiatives able to approach and inform family caregivers, fostering their access to healthcare and social benefits.

\section{CONCLUSION}

The analysis of the perceptions of family caregivers of children and adolescents with cerebral palsy on caring evidences that they mostly express positive feelings, such as love, affection, happiness, privilege, overcoming, learning and pleasure of caring. However, it should be pointed out that a significant number of those caregivers associate their own quality of life with the cared subjects' well-being, once in their accounts, the evaluation of their own health is correlated to the life conditions that they offer to the subjects they care for. Similarly, in the accounts of most participants, their rights to a healthy life are blurred with the cared subjects' rights.

Keeping in mind the reports by caregivers of children and adolescents in this study, it is perceived the need for health professionals to implement actions which enable them to approach and help these family members in their daily caring tasks. It deems necessary that professionals, involved in caring for children and adolescents with cerebral palsy, to acknowledge that family caregivers also require care to keep themselves healthy and able to continue caring well. That is only possible when caregivers are able to make choices and distinguish their own needs and wishes from those of the cared subjects.

\section{REFERENCES}

1. Santana MJA, Rabinovich EP. Concepções de cuidadores de deficiência: realidade atual e perspectivas futuras da criança com paralisia cerebral em uma abordagem centrada na família. Saúde Coletiva. 2012;55(9):24-9.

2. Baquero RVA. Empoderamento: instrumento de emancipação social?- uma discussão conceitual. Rev Debates. 2012;6(1):173-87.

3. Rethlefsen SA, Ryan DD, Kay RM. Classification systems in cerebral palsy. Orthopedic Clinics of North America. 2010;41(4):457-67.

4. Snider L, Majnemer A, Darsaklis V. Virtual reality as a therapeutic modality for children with cerebral palsy. Developmental Neuro Rehabilitation. 2010;13(2):120-8.

5. Rosenbaum P, Nigel P, Goldstein M, Bax M. A report: the definition and classification of cerebral palsy. Developmental Medicine \& Child Neurology. 2007;49(6):480.

6. Brasil. Ministério da Saúde. Diretrizes de atenção à pessoa com paralisia cerebral. Secretaria de Atenção à Saúde, Departamento de Ações Programáticas Estratégicas. Comunicação e Educação em Saúde. Brasília: 2013.

7. O'Shea M. Cerebral palsy. Semin Perinatol. 2008;32(1):35-41. doi: 10.1053/j. semperi. 2007. 12.008.S0146-0005(07)00148-6 [pii] [PubMed] [Cross Ref]

8. Yeargin-Allsopp M, Van Naarden BK, Doernberg NS, Benedict RE, Kirby RS, Durkin MS. Prevalence of cerebral palsy in 8-year-old children in three areas of the United States in 2002: a multisite collaboration. Pediatrics. 2008;121(3):547-54. doi: 10.1542/peds. 2007-1270. 121/3/547 [pii] [PubMed] [Cross Ref]

9. Houtrow A, Kang T, Newcomer R. In-home supportive services for individuals with cerebral palsy in California. J Pediatr Rehabil Med. 2012;5(3):187-95. doi:10.3233/PRM-2012-0211. 
10. Instituto Brasileiro de Geografia e Estatística - IBGE. Censo demográfico 2010: características gerais da população, religião, pessoas com deficiência. IBGE. [Internet]. 2012 [acesso em 24 de abril de 2015]. Disponível em: http://censo2010.ibge.gov. br/

11. Rodrigues MPG. Questionário de avaliação da sobrecarga do cuidador informal-versão reduzida. [Dissertação] Porto (Portugal): Escola Superior de Enfermagem do Porto, 2011.

12. Brasil. Conselho Nacional de Saúde. Resolução no 466, de 12 de dezembro de 2012. Regulamenta as pesquisas envolvendo seres humanos. Brasília: 2012.

13. Bardin L. Análise de conteúdo. 7. ed. São Paulo: Edições 70, 2011.

14. Oliveira MF, Silva LM, Oliveira FT, Gomes TT. Quality of life of caregivers of patients with cerebral palsy. J Health Sci Inst. 2013;31(4):412-14.

15. Mello R, Ichisato SMT, Marcon SS. Percepção da família quanto à doença e ao cuidado fisioterapêutico de pessoas com paralisia cerebral. Rev Bras Enferm. 2012;65(1):104-9. doi. org/10.1590/S0034-71672012000100015

16. Santos AAS, Vargas MM, Oliveira CCC, Macedo IAB. Avaliação da sobrecarga dos cuidadores de crianças com paralisia cerebral. Cienc Cuid Saúde. 2010;9(3):503-9.

17. Miura RT, Petean EBL. Paralisia cerebral grave: o impacto na qualidade de vida de mães cuidadoras. Mudanças - Psicologia da Saúde. 2012;20(1-2):7-12.

18. Silva CX, Brito ED, Sousa FS, França ISX. Criança com paralisia cerebral: qual o impacto na vida do cuidador? Rev Rene. 2010;11(esp):204-14.

19. Oliveira MFS, Silva MBM, Frota MA, Pinto JMS, Frota LMCP, Sá FE. Qualidade de vida do cuidador de crianças com paralisia cerebral. RBPS. 2008;21 (4):275-80.

20. Dantas MSA, Collet N, Moura FM, Torquato IMB. Impacto do diagnóstico de paralisia cerebral para a família. Texto Contexto Enferm. 2010;19(2):229-37. doi.org/10.1590/SO104-07072010000200003

21. Guyard A, Fauconnier J, Mermet MA, Cans C. Impact on parents of cerebral palsy in children: a literature review. Archives de Pediatrie: Organe Officiel de la Societe Francaise de Pediatrie. 2011;18(2):204-14. PMID:21196101
22. Kluthcovsky ACG, Takayana AMM. Qualidade de vida: aspectos conceituais. Rev Salus. 2007;1(1):13-5. ISSN1980-2404.

23. Silva RMM, Lui AM, Correio TZHOC, Arcoverde MAM, Meira MCR, Cardoso LL. Busca ativa de crianças com necessidades especiais de saúde na comunidade: relato de experiência. Rev Enferm UFSM. 2015;5(1):178-85.

24. Brasil, Presidência da República. Cartilha do Censo 2010 - Pessoas com Deficiência Secretaria e Direitos Humanos da Presidência da República (SDH/PR) / Secretaria Nacional de Promoção dos Direitos da Pessoa com Deficiência (SNPD) / Coordenação-Geral do Sistema de Informações sobre a Pessoa com Deficiência; Brasília: SDH-PR/ SNPD, 2012.

25. Simões CC, Silva L, Santos MR, Misko MD, Bousso RS. A experiência dos pais no cuidado dos filhos com paralisia cerebral. Revista Eletr Enf. [Internet]. 2013 [acesso em 24 de abril de 2015];15(1):138-45. Disponível em: http://dx.doi.org/10.5216/ree. v15i1.13464.

26. Brasil. Guia Prático do Cuidador. Secretaria de Atenção à Saúde. Secretaria de Gestão do Trabalho e da Educação na Saúde. Série A. Normas e Manuais Técnicos. Brasília - DF: 2008.

27. Manoel MF, Teston EF, Waidman MAP, Decesaro MN, Marcon SS. As relações familiares e o nível de sobrecarga do cuidador familiar. Esc Anna Nery. 2013;17(2):346-53. doi.org/10.1590/ S1414-81452013000200020

28. Panhoca I, Pupo ACS. Taking care of the caregiver: valuing of the quality of life of the aphasics caregivers. Rev CEFAC. 2010;12(2):299-307. doi. org/10.1590/S1516-18462010005000034.

29. Nóbrega VM, Collet N, Silva KL, Coutinho SED. Rede e apoio social das famílias de crianças em condição crônica. Rev. Eletr Enf. [Internet]. 2010 [acesso em 10 de abril de 2015];12(3):431-40. Disponível em: http://dx.doi.org/10.5216/ree. v12i3.7566. 